\title{
Mastitis and Breast Abscess in a Newborn
}

\author{
Yenidoğanda Mastit ve Meme Apsesi
}

Ergin Çiftçi'(iD), Hatice Kübra Konca'(iD), Esra Çakmak Taşkın(ID), Gül Arga'(i ID), Seval Özen'(iD ), Fevziye Çoksüer(ID), Halil Özdemir'(ID), Erdal İnce'(ID)

${ }^{1}$ Division of Pediatric Infectious Diseases, Department of Pediatrics, Ankara University School of Medicine, Ankara, Turkey

Cite this article as: Çiftçi E, Konca HK, Çakmak Taşkın E, Arga G, Özen S, Çoksüer F, et al. Mastitis and breast abscess in a newborn. J Pediatr Inf 2020;14(2):e86.

The 30-day girl was brought with the complaint of restlessness, decreased sucking, redness and swelling in the right breast. It was learned that the patient's restlessness started a few days ago, her sucking decreased, redness appeared on her right breast two days ago, and her swelling has gradually increased. The patient had no fever. The examination revealed redness and warmness of the skin around the right breast, and fluctuating swelling about $2 \mathrm{~cm}$ in diameter. The patient was diagnosed with mastitis and breast abscess. Intravenous ampicillin-sulbactam treatment was started. Gram-positive cocci was observed in the abscess drainage material, and Staphylococcus aureus was isolated in culture. The same agent was also detected in the nasal swab cultures of the mother and baby, and both were given nasal topical mupirocin. In the follow-up, the patient's mastitis findings regressed. The treatment was completed by giving ampicillin-sulbactam 10 days followed by oral amoxicillin-clavulanic acid for four days.

Mastitis, an infection of the breast tissue, is rarely seen in newborns. It mostly occurs due to the rubbing or squeezing of physiological breast tissue hypertrophy by family members. This causes disruption of skin integrity and invasion of microorganisms into subcutaneous tissues in the breast area. Thus, mastitis and/or breast abscess develop. The most common clinical findings are swelling, redness, and warmness in the affected breast, rarely discharge from the nipple may be observed. If mastitis turns into abscess, the fluctuating mass can be palpated. Ultrasonography may help differentiate mastitis from breast abscess and guide the treatment. The most common cause of neonatal mastitis is $S$. aureus. It is usually sufficient to give antibiotic therapy for 10 to 14 days.

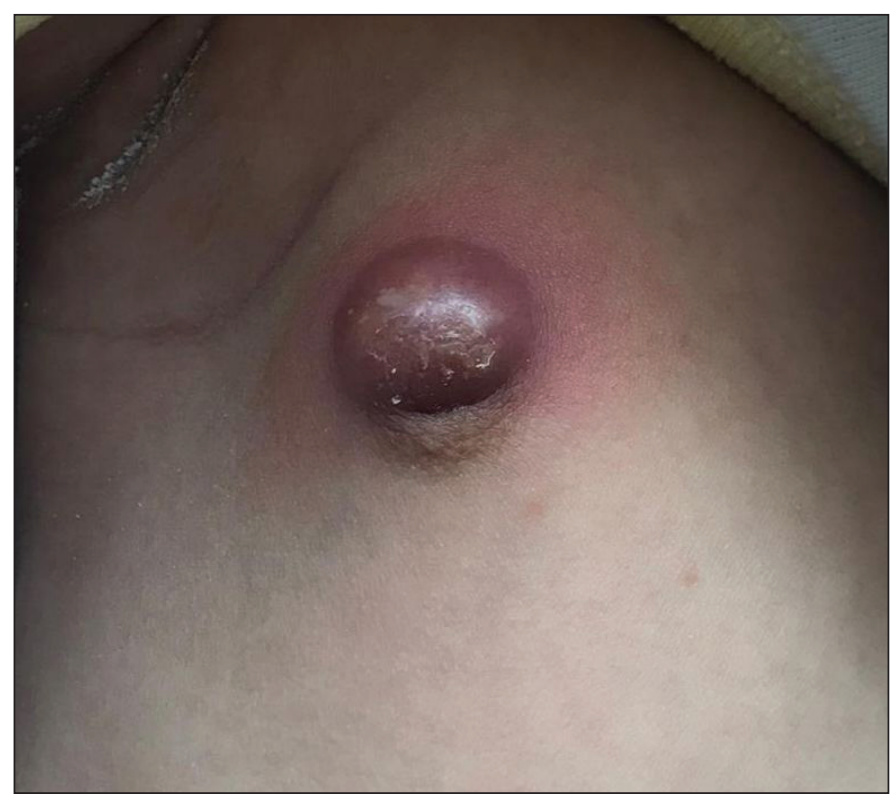

\footnotetext{
Correspondence Address/Yazışma Adresi

Ergin Çiftçi

Ankara Üniversitesi Tıp Fakültesi,

Çocuk Sağlığı ve Hastalıkları Anabilim Dalı,

Çocuk Enfeksiyon Hastalıkları Bilim Dalı,

Ankara-Türkiye

E-mail: erginciftci@gmail.com
}

Received: 26.06 .2020 